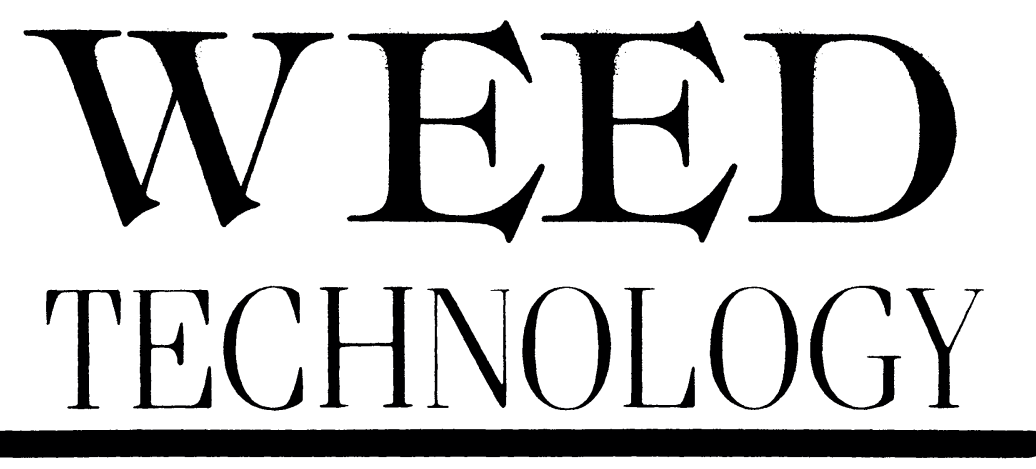

A Journal of the Weed Science Society of America

VOLUME 4 OCTOBER-DECEMBER 1990

NUMBER 4

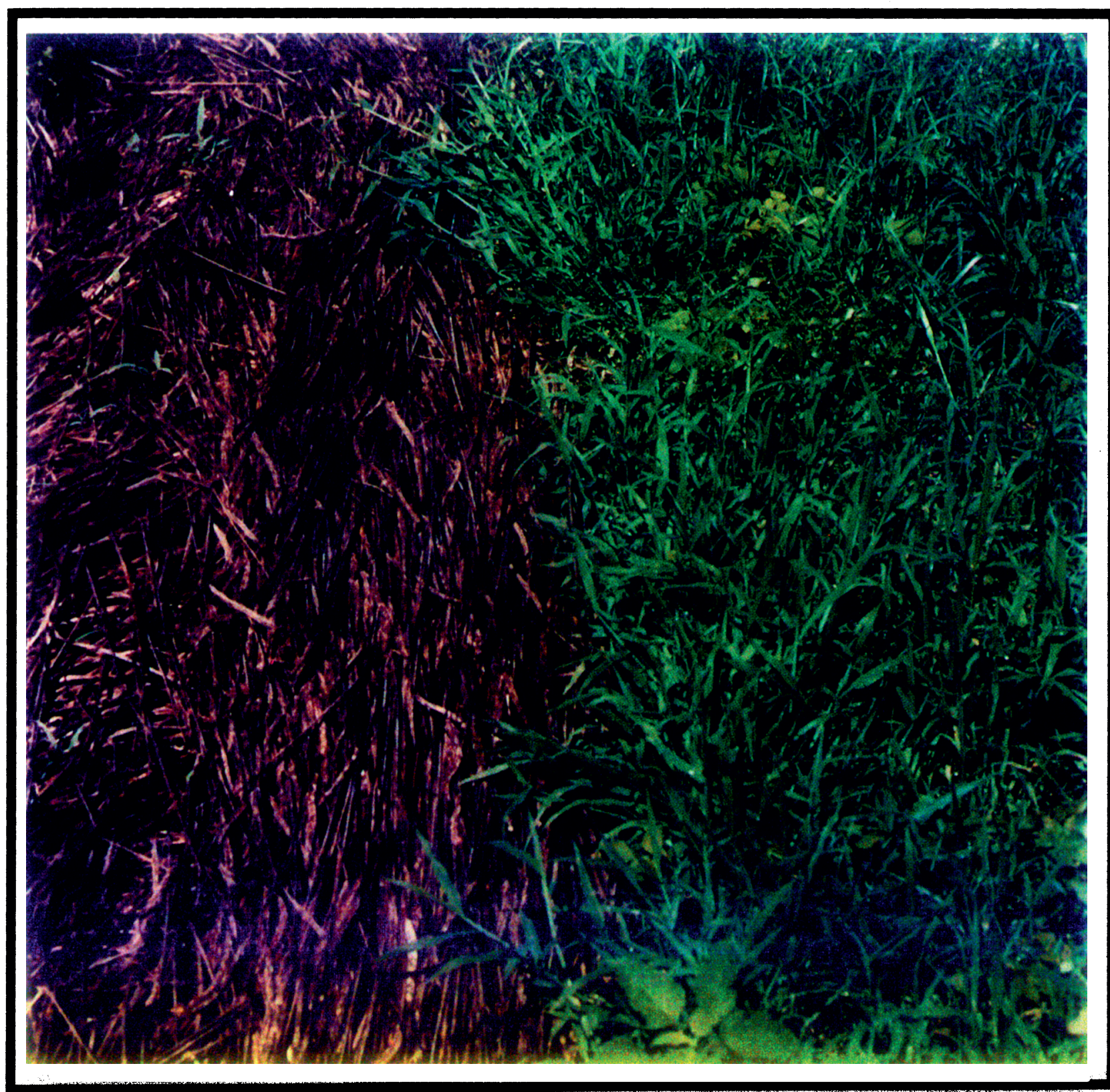




\section{WEED TECHNOL(G)}

A Journal of the Weed Science Society of America

Weed Technology published quarterly beginning each January-March issue, is included along with Weed Science and WSSA Newsletter to Weed Science Society of America (WSSA) members. Annual membership costs $\$ 50$ with $\$ 20$ student affiliate memberships on a calendar year basis only.

Weed Technology, subscriptions are $\$ 30$ per year (four issues per volume). New subscriptions begin with the January-March issue. Subscribers, including libraries and institutions, can obtain both Weed Science (volume of six issues per year) and Weed Technology for $\$ 80$ annually.

Changes of mailing address, inquiries about copies lost in the mail, and requests for back issues and for information about placing advertisements and about receiving journals, membership and subscriptions should be sent to WSSA, 309 W. Clark St., Champaign, IL 61820 . Send dues by December 1 each year. Claims for copies lost in the mail must be received within 30 days (90 days foreign) of the issue date to insure replacement at no charge.

Send manuscripts to Chester L. Foy, Editor, Weed Technology, Dept. of Plant Pathology, Physiology, and Weed Science, Virginia Polytech. Institute \& State Univ., 503 Price Hall, Blacksburg, VA 24061-0331. Directions for contributors are published in the April-June issue of Weed Technology. Authors are charged $\$ 50$ per page (nonmembers $\$ 100$ ) to cover a portion of publication costs. The Editor can exempt page charges in advance when justified.

Weed Technology (ISSN 0890-037X) is published by the Weed Science Society of America. Copyright 1991 by the Weed Science Society of America. Printed in USA. All rights reserved. Reproduction in part or whole is prohibited. Return POD Form 3579 to WSSA, 309 W. Clark St., Champaign, IL 61820 (AC/ 217-356-3182).

\section{WSSA OFFICERS}

L. W. Mitich, President

J. R. Abernathy, President Elect

J. Antognini, Vice President

H. M. LeBaron, Past President

A. S. Hamill, Secretary

J. F. Ellis, Treasurer

B. Truelove, Editor-in-Chief

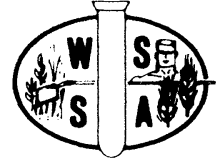

\section{Sustaining Members}

December 31, 1990

A \& L Agricultural Laboratories ACRES Agric. Custom Research Agri-Growth Research Inc.

Agrolinz Inc.

Allen Machine Works

American Agricultural Services Inc.

American Cyanamid Company

The Andersons

BASF Corporation

Battelle

Calgene

CIBA-GEIGY Canada Inc.

CIBA-GEIGY Corporation

Deere \& Company

De Soto, Inc.

DuPont Agricultural Products

Eli Lilly \& Company

Environmental Technologies Institute Inc.

Fermenta ASC Corporation

FMC Corporation

Gandy Corporation

Griffin Corporation

Growmark Inc.

Gylling Data Management, Inc.

Heartland Technologies, Inc.

Hoechst-Roussel Agri-Vet

$\mathrm{ICl}$ Americas, Inc. ICMS Inc.

Kincaid Equipment Manufacturers Landis intemational Inc.

Lehigh Agricultural \& Biological Service LI-COR, Inc. Marbicon Inc. Micro Simplified Inc.

Minnesota Valley Testing Lab

Mobay Corp./Ag Chem. Div.

Monsanto Company

Mycogen Company

Nippon Soda Company Ltd.

NOR-AM Chemical Company

OMNI-DATA International

Pan-Agricultural Labs., Inc.

PBI/Gordon Corporation

Pioneer Overseas Corporation Plant Sciences Inc.

Research Development Alternatives

Research Options, Inc.

Rhone Poulenc Inc.

Rogers Engineering inc.

Rohm \& Haas Company

Sandoz Crop Protection

O. M. Scott \& Sons Company

Spraying Systems Company

SSI Mobley Company, Inc.

Stewart Agricultural Research Service Inc.

Sumitomo Chemical America Inc.

Terra International inc.

Uniroyal Chemical Corporation

Watson Consulting and Research Inc. Woed Systems, Inc.

Winterstelger America Inc. 


\section{WEED \\ TECHNOLOGY

\section{Table of Contents}

\section{Technology Notes}

697 News Notes of General Weed Science Interest

\section{-Feature}

701 Effect of Selected Pesticides on Survival of Colletotrichum gloeosporioides $\mathbf{f}$. sp. malvae, a Bioherbicide for Round-leaved Mallow (Malva pusilla). Nelson T. Grant, Elizabeth Prusinkiewicz, Roberte M.D. Makowski, Britt Holmstrom- Ruddick, and Knud Mortensen

716 Herbicide Interactions with Colletotrichum gloeosporioides $\mathrm{f}$. sp. malvae a Bioherbicide for Round-leaved Mallow (Malva pusilla) Control. Nelson T. Grant, Elizabeth Prusinkiewicz, Knud Mortensen, and Roberte M.D. Makowski

\section{-Research}

724 Factors Influencing Winter Wheat (Triticum aestivum) Injury from Sulfonylurea Herbicides. Kenneth L. Ferreira, Thomas K. Baker, and Thomas F. Peeper

731 Weed Control in No-tillage and Conventional Com (Zea mays) with ICIA-0051 and SC- 0774. John S. Wilson and Chester L. Foy

739 Effect of Seeding Depth, Herbicide, and Variety on Sugarbeet (Beta vulgaris) Emergence, Vigor, and Yield. Robert G. Wilson, John A. Smith, and C. Dean Yonts

743 Common Cocklebur (Xanthium strumarium) Interference in Snap Beans (Phaseolus vulgaris). Philip E. Neary and Bradley A. Majek

749 Improving the Efficiency of Sethoxydim in Flax. George H. Friesen and David A. Wall

754 Efficacy and Economic Analysis of Texas Panicum (Panicum texanum) Management Systems in Corn (Zea mays). W. Carroll Johnson, III, and Benjamin G. Mullinix, Jr.

759 Cotton (Gossypium hirsutum) Response to Glyphosate Spot Applied. R. Brent Westerman and Don S. Murray

- Peer reviewed papers.

\section{Cover}

Use of rye (Secale cereale $\mathrm{L}$.) residues (left) to suppress weed emergence and growth. Rye was fall-planted and desiccated the following spring with $1.12 \mathrm{~kg} / \mathrm{ha}^{-1}$ glyphosate. The picture was taken more than $6 \mathrm{wk}$ after treatment. Bare ground (right) was also treated with glyphosate. This photograph was awarded second place (Print Division) in the 1990 WSSA Photography Contest, Montreal, Canada, and was taken by Reid J. Smeda, USDA, ARS, Southern Weed Science Laboratory, Stoneville, MS 38776. 
765 Imazethapyr Efficacy with Adjuvants and Environments. John D. Nalewaja, Jerzy Palczynski, and Frank A. Manthey

771 Field Bindweed (Convolvulus arvensis) Control with Imazapyr. Monty G. Schoenhals, Allen F. Wiese, and Mark L. Wood

776 Shattercane (Sorghum bicolor) Control in Soybeans (Glycine max) with Preplant and Postemergence Herbicides. Michael S. Defelice

781 Sequential Herbicide Treatments for Corn (Zea mays) Planted into Mixed-Species Perennial Sod. Douglas D. Buhler and Richard T. Proost

787 Inheritance of Sulfonylurea Herbicide Resistance in Lactuca spp. Carol A. Mallory-Smith, Donald C. Thill, Michael J. Dial, and Robert S. Zemetra

791 Performance of Imazethapyr on Pulse Crops. Najib Malik and Lawrence Townley-Smith

799 Velvetleaf (Abutilon theophrasti) Interference with Cotton (Gossypium hirsutum). Brenda S. Smith, Don S. Murray, and David L. Weeks

804 Growing Broomrape (Orobanche spp.) in a Soilless System. Reuven Jacobsohn, Chester L. Foy, and Kela Marton

808 Ethephon Reduction of Redroot Pigweed (Amaranthus retroflexus) Seed Populations. Grant H. Egley

814 Horseweed (Conyza canadensis) Control in Full-Season No-Till Soybeans (Glycine max). Carroll M. Moseley and Edward S. Hagood, Jr.

819 Lactofen Systems for Broadleaf Weed Control in Peanuts (Arachis hypogaea). John W. Wilcut, Charles W. Swann, and Henry B. Hagwood

824 Diffusive Resistance and Transpiration of Quackgrass (Elytrigia repens) Following Postemergence Herbicides. Mark C. Trimmer and Dean L. Linscott

828 Assessing Herbicide Phytotoxicity with Covariance Analysis. S. Kent Harrison and Emilie E. Regnier

833 Interference and Critical Time of Removal of Hemp Sesbania (Sesbania exaltata) in Cotton (Gossypium hirsutum). Charles T. Bryson

838 Crop Response and Weed Control from New Herbicide Combinations in Water-Seeded Rice (Oryza sativa). James E. Hill, Stacey R. Roberts, D. E. Bayer, and J. F. Williams

843 Growth and Development of Bulbous Oatgrass (Arrhenatherum elatius var. bulbosum). Karin Tanphiphat and Amold P. Appleby

849 Growth and Development of Giant Burreed (Sparganium eurycarpum). John W. Leif III and Ervin A. Oelke

855 Carryover Injury of Clomazone Applied in Soybeans (Glycine max) and Fallow. William H. Ahrens and E. Patrick Fuerst

862 Woolly Croton (Croton capitatus) and Bitter Sneezeweed (Helenium amarum) Control in the Blackland Prairie of Texas. Rodney W. Bovey and Robert E. Meyer

866 Effect of Paraquat on Yield and Market Grade of Peanut (Arachis hypogaea) Genotypes. David A. Knauft, Daniel L. Colvin, and Daniel W. Gorbet

871 Italian Ryegrass (Lolium multiflorum) Control in Small Grains with Flurtamone. David C. Bridges

876 Newly Seeded Alfalfa (Medicago sativa) Tolerates Glyphosate and SC-0224 at Doses That Control Dodder (Cuscuta spp.). Jean H. Dawson

880 Dodder (Cuscuta spp.) Control in Newly Seeded Alfalfa (Medicago sativa) With Glyphosate. Jean H. Dawson

886 Seed Protectants Safen Sorghum (Sorghum bicolor) Against Chloroacetamide Herbicide Injury. Chester L. Foy and Harold L. Witt 
892 Effects of Weed Control and Irrigation on the Growth of Young Pecans. Michael G. Patterson, Glenn Wehtje, and William D. Goff

895 Response of Bahiagrass (Paspalum notatum) to Plant Growth Regulators. B. Jack Johnson

900 Effect of Herbicide Application Timing on Johnsongrass (Sorghum halepense) and Pitted Morningglory (Ipomoea lacunosa) Control. David R. Shaw, Sunil Ratnayake, and Clyde A. Smith

904 Factors Affecting Chloroacetanilide Injury to Corn (Zea mays). Loston Rowe and Donald Penner

-Notes

907 Low Volume Invert Emulsions for Purple Nutsedge (Cyperus rotundus) Control. Charles T. Bryson, Gene D. Wills, and Paul C. Quimby

910 Effects of $\mathrm{CO}_{2}, \mathrm{~N}_{2}$, Air, and Nitrogen Salts on Spray Solution pH. Ronald W. McCormick

-Education

913 A Tractor Mounted Sampler for Obtaining Large Soil Columns. David S. Walker, J. David O'Dell, Jeff D. Wolt, G. Neil Rhodes, Jr., and John G. Graveel

\section{Intriguing World of Weeds}

918 Baryardgrass. Larry W. Mitich

\section{Helpful Hints for Technical Writing}

921 Be Sure Pronouns and Antecedents Agree. J. H. Dawson

\section{WSSA Communications}

922 WSSA Position Statements on Timely Issues

928 Recognition of Reviewers and Associate Editors

930 Erratum

931 Author Index, Volume 4

933 Subject Index, Volume 4

EDITOR

Chester L. Foy

TECHNICAL EDITOR

Richard W. Rhoades
ASSOCIATE EDITORS

Jon P. Chernicky

Clyde C. Dowler

Joan Dusky

Robert Hayes

Kenneth J. Kirkland

James R. Martin

Tim Obrigawitch
Thomas F. Peeper

Walter A. Skroch

Phillip Stahlman

Edward W. Stoller

Joe Street

Donald C. Thill 